\title{
The Effect of Explicit Strategy Instruction on L2 Oral Production of Iranian Intermediate EFL Learners: Focusing on Accuracy, Fluency and Complexity
}

\author{
Mansoor Tavakoli \\ University of Isfahan, Isfahan, Iran \\ Email: Mr.tavakoli14@gmail.com \\ Hossein Vahid Dastjerdi \\ University of Isfahan, Isfahan, Iran \\ Email: h_vahid@yahoo.com \\ Masood Esteki \\ University of Isfahan, Isfahan, Iran \\ Email: Masoodesteki@gmail.com
}

\begin{abstract}
Communicative strategies have attracted attention during the last few decades. Research on communicative strategies has mainly focused on the effect of teaching these strategies in second language classrooms. There is still a question under investigation as to whether communicative strategies have fulfilled the promise their proponents have claimed. With an aim to determine the effects of strategy instruction on second-language oral production, this paper examined the effects of explicit strategy instruction on Iranian intermediate EFL learners' oral production with regard to complexity, accuracy, and fluency. 40 homogenous learners were randomly assigned to two groups. The experimental group received 8 lessons on strategies whereas the control group did not. The findings of a pretest and a posttest interview revealed that learners' oral performance improved in complexity, accuracy, and fluency.
\end{abstract}

Index Terms - communicative strategies, complexity, accuracy, fluency

\section{INTRODUCTION}

During the past two decades, the concept of communicative competence has become an icon in the area of foreign language teaching. The notion of communicative competence came into existence when Dell Hymes (1972) called for the study of language in context. Hymes challenged Chomsky's (1965) view of a theory of forms, which deals with language knowledge, including phonological, morphological, syntactic, and lexical rules. For Hymes, to speak of language as an entity outside the context of its use is meaningless. Indeed, he believes that communicative competence is the knowledge of not only if something is formally possible in a language, but also the knowledge of whether it is feasible, appropriate, or done in a particular speech community. Communicative competence, as Richards and Schmidt (2002) also mention, includes grammatical competence, sociolinguistic competence, discourse competence, and strategic competence. The above-mentioned aspects of competence have each attracted attention in copious lines of research; however, strategic competence, which refers to knowledge of communication strategies that can compensate for weakness in other areas, constitutes the general focus of this research.

Strategic competence, according to Canale and Swain (1980, p. 30), is defined as "verbal and non-verbal communication strategies that may be implemented to compensate for breakdowns in communication due to performance variables or to insufficient competence. Communication strategies, then, are expected to help tackle problems in performing and understanding communicative acts. These problems may stem from gaps in linguistic or pragmatic knowledge or from low accessibility of such knowledge (Faerch \& Kasper, 1986).

Learners are constantly bombarded with an overwhelming number of thoughts they would like to express. Dressing the thoughts into words obviously calls for a good command of L2, which learners may not have. Even in case of proficient language learners, there may be times at which they do not have access to the required lexical or grammatical patterns due to memory failure or any other reasons.

The prime concern, then, for the learners and consequently for the language researchers is to investigate possible ways to circumvent this problem. As mentioned above, breakdowns in communication due to performance variables or to insufficient competence should be compensated for by the use of communication strategies when called into action. 
Faerch and Kasper (1986) state that "there exists an inevitable gap between what learners are taught and what they need in present and future situations" (p. 179). In order to bridge this gap, learners are in need of "strategic competence" as referred to by Canale and Swain (1980).

Second language learners are likely to find themselves in a situation where they need to express a lexical item in the target language but do not have the linguistic resources to do so. Some learners are able to paraphrase or make use of gestures to describe the meaning of the term. That is, they are using a communication strategy to express the intended meaning. Others, however, avoid the term or resort to silence.

Bridging the gap between what learners know and what they need to express requires the learner to have another competence, referred to as "strategic competence" by Canale and Swain (1980). The authors point out that the concept of communicative competence should be understood in a broader sense and should include strategic competence in addition to linguistic and sociolinguistic competence. This framework of communicative competence has provided a theoretical basis to communicative approaches to second language teaching and testing (Bachman, 1990).

When there is a deficit in the target language resources required to meet the communicative needs, learners have to make use of all the means available to get the message across. This is the time when they should employ communication strategies to express their ideas and to avoid communication breakdowns. Strategies are specific actions, behaviors, steps, or techniques students use -often consciously- to improve their progress in apprehending, internalizing, and using the L2 (Oxford, 1990). A learner is claimed to be strategically competent when s/he does not give up easily in case of difficulty and tries his best to communicate the message with the strategies s/he can make use of.

In this sense, the learner who acquires the target language in a natural environment, in which the focus is on understanding and getting the meaning across, will have more opportunities and more motivation to use communication strategies effectively. In contrast, learners in language classrooms often have fewer opportunities and less motivation to use communication strategies. They may not even be aware of the advantages of communication strategies when they encounter linguistic difficulties in their communication. Therefore, the issue of how classroom language teaching could help learners with limited second language resources communicate effectively has become a great concern of second language researchers and teachers.

There has been little research designed to investigate the effect of the teaching of communication strategies on language learners' strategic performance. Some researchers, however, have touched this area and found some promising results.

To examine the effects of awareness-raising about communication strategies on students' strategic performance, Salomon and Marsal (1997) conducted a study of two intermediate college French classes. One class was encouraged to use circumlocution strategy; the other was not. Pretest and posttest were used to measure gains in circumlocution. At the end of the term, both groups significantly improved their ability to circumlocute. Although the findings show no significant differences in statistical results between the two groups, qualitative data revealed that the experimental group could focus better on the salient features of the lexical terms and, therefore, could circumlocute more effectively.

Brodersen and Gibson (1982, cited in Faerch \& Kasper, 1986), however, have been known as the two researchers among pioneers who have carried out systematic research examining the effect of strategy instruction on the strategy use of language learners. The subjects of the study were Danish learners of English, and the study had a one group pretest-posttest design. The teaching program consisted of a discussion of the effectiveness of strategy use based on the students' conversations with a native speaker of English (which had been videotaped prior to the experiment) and direct teaching of communication strategies with role-play activities. The researchers found that, in terms of strategy use, the students with the intermediate level of proficiency made much more progress, whereas those with high or low proficiency showed no measurable development. However, the attitude of the class as a whole changed. That is, more students were willing to use strategies when they did not have the exact term in English.

Having the same goal in mind, Mosiori (1991) conducted a study in an attempt to obtain empirical data on the educational potential of strategy teaching to language learners. Her study investigated the impact of consciousnessraising about communication strategies on the strategic performance of 30 university students of French, who formed a control group and an experimental group. Both groups were provided with opportunities to use communication strategies through such activities as definitions of concepts, storytelling tasks, or free communication. However, the experimental group also received consciousness-raising about communication strategies, which included presentation of principles of communication strategy use, and provision of analytical feedback and of lexical items useful for verbalizing communication strategies. A pretest, posttest, and a three-week-delayed posttest were administered to both groups. Retrospective report data, first language data, and baseline data were also collected. The results show that, for the most part, there were no significant differences between the two groups' gain scores. However, the experimental group displayed more success in using communication strategies and showed greater willingness to provide more information in their communication.

The study conducted by Dornyei (1995) showed more positive effects of strategy training on 109 Hungarian secondary students, who were divided into three groups: one experimental group and two control groups. The experimental group attended a training session of three strategies: avoidance, circumlocution, and pause fillers. One control group received a conversational training supplement, and the other received no treatment. A pretest and a posttest were used to elicit the language from the students, and the data collected from these two tests were compared. 
The findings indicated that there was a significant improvement in oral skills of the experimental group. The students in this group used circumlocution more effectively in expressing their ideas and employed a greater frequency of fillers and circumlocution than the control groups in the posttest.

Dula (2001) partly replicated Dornyei's study with American students of French at the university level. The students were randomly assigned to an experimental group and a control group. The experimental group received two weeks of training in the use of circumlocution, fillers, and request for clarification. Both groups were asked to do three tests: a pretest, an immediate posttest, and a delayed posttest. The results revealed an increase in the use of circumlocution and a decrease in the use of requests for clarification of the experimental groups. Yet, the use of fillers of this group increased in the first two tests but decreased in the last test. By contrast, the control group's use of circumlocution and fillers decreased over the three tests. The use of requests for clarification of this group, however, increased from the pretest to the immediate posttest, but remained the same in the delayed posttest. The findings, therefore, showed some beneficial influence of the direct teaching of communication strategies on language learners' strategic performance.

Learners of French were also the research participants in a study conducted by Scullen and Jourdain (1999). The researchers investigated the effects of the explicit teaching of circumlocution on two groups of students-experimental and control-who studied French at an American university. Both the experimental group and the control group completed a pretest, three practice sessions, and a posttest. The experimental group received a single session of instruction in the use of circumlocution immediately prior to each practice session. Results showed that both groups made significant gains in successful use of circumlocution over time, but the between-group difference on the posttest was not significant. These results, however, might have been influenced by the short period of training and by the small, unequal group size (17 students in the experimental group and 8 in the control group).

Unlike the other researchers who were more interested in examining the impact of strategy teaching on intermediate or advanced learners, Brett (2001) wanted to explore whether or not communication strategies could be taught to language learners at the beginning level. She conducted a study in which beginners of German were instructed in a variety of strategies: turn-taking phrases, requests for help, clarification and repetition, greetings, and pause fillers. Data were collected from questionnaires and audio-recordings of pairs of students' collaboration on speaking tasks in class activities and in an oral test. The researcher found that the students could employ the communication strategies they had learned in their English speaking. Yet, they used a smaller range of the strategies in the test than in less formal situations. They also used repetition and self-talk as a means of gaining thinking time but did not utilize any pause fillers in their interactions. Finally, there seemed to be an influence of the students' personality and their language proficiency on their strategy use.

More recently, Rossiter (2003) reported on the effects of communication strategy instruction on second language performance (communicative success, speech rate, message abandonment) and on the use of communication strategies. The participants were two classes of adult immigrants who attended a full-time intermediate proficiency ESL (English as a second language) program at a postsecondary institution in Canada. One class received 12 hours of direct communication strategy training, and the other served as a comparison group. Three tests were given to the learners: pretest, immediate posttest, and delayed posttest. Results showed a direct effect of communication strategy instruction on the range of strategies used by the treatment group in the object description task. Yet, the instruction appeared to be less effective in the narrative picture task, where the learners were able to avoid describing one unknown aspect by identifying another element for which the language was known.

In general, the findings of these studies show that the teaching of communication strategies had certain positive effects on the learners' strategic performance, which could, to some extent, help them cope with their communicative problems. It also helped make them more aware of the advantages of strategy use and thus become more willing to risk using communication strategies in their communication. In addition, the strategy instruction could be given not only to learners whose second language competence has developed sufficiently for strategy use (Brodersen \& Gibson, 1982; Dornyei, 1995; Dula, 2001; Mosiori, 1991; Rossiter, 2003) but also to those at the beginning level of language learning (Brett, 2001). However, there are some notable differences in the results of the studies. The teaching of fillers, for example, proved not to be very successful in Dula's and Brett's studies but revealed very significant results in Dornyei's experiment. Also, while the experimental group in Dornyei's research displayed considerable progress in the employment of the studied strategies compared to that of the control groups, the experimental and the control group in Mosiori's experiment showed no significant differences in their strategic performance. These differences, as pointed out by Yule and Tarone (1997), might result from the differences in the training situations and categories of analysis.

All in all, although there have been some empirical studies aimed at investigating the effects of strategy teaching on language learners' strategic competence, the results are far from conclusive. Hence, the present study is founded on the assumption that L2 learners need to attend to communicative strategies in order to manifest a better performance in expressing their thoughts and ideas.

\section{PURPOSE AND RESEARCH QUESTIONS}

Given the aforementioned points, this study seeks to investigate whether it is effective to teach learners how to use strategies (i.e., circumlocution, approximation, all-purpose words, lexicalized fillers) in order to improve students' oral productions with specific focus on complexity, accuracy, and fluency. 
Based on the purpose and the problem under focus in the present study, the following research question was addressed:

Does explicit strategy instruction have any effects on Iranian EFL learners' oral production in terms of complexity, accuracy, and fluency?

\section{METHOD}

\section{A. Participants}

Intermediate EFL learners at Isfahan language schools formed the population. These learners, who participated in English language classes in summer 1389, were called intermediate according to the schools' organization of different English courses, which ranged from beginner to advanced levels. Yet, in order to thoroughly gauge the learners' language proficiency and make sure they were intermediate, obligation was felt to utilize an OPT and a pre-test interview as further instruments of assessment.

At the beginning, 90 intermediate EFL learners were selected from the intermediate level classes of an English language center in Isfahan. They were all male students whose age ranged from 17 to 24 and who voluntarily consented to cooperate. Then, an Oxford Placement Test (OPT) was administered for the sake of homogeneity and 65 homogenous learners were selected. However, it was deemed necessary to run interviews to further ensure the learners' homogeneity with regard to oral performance. This was done due to the fact that OPT mostly measures learners' vocabulary and grammar and may not be a good indicator to learners' oral proficiency, which was the core concern of this study. The pretest interview was a researcher-made one and consisted of ten question of high frequency in everyday conversations, such as family, free time, hobbies, field of study, etc. (Appendix A). Out of the 65 learners who participated in the interview, 40 were chosen to serve as the participants of the study. Later, they were randomly (using Tables of random numbers) assigned to two groups (20 participants each).

\section{B. Research Design}

The present study was conducted to investigate the potential effect of strategy instruction on Iranian intermediate EFL learners' oral performance with regard to complexity, accuracy, and fluency. The design of study is experimental with a between-groups design in order to probe into the research questions. The independent variable is communication strategy instruction. The dependent variable is learners' speaking ability which was assessed using the three analytic measures of fluency, complexity, and accuracy.

\section{Treatment}

Four communication strategies were selected in this study. For the sake of instructing the participants, eight lessons were prepared to be taught in the experiment group. They are in turn described below:

- Circumlocution: It is viewed as the most important achievement strategy and a major component of strategic competence (Canale \& Swain, 1980). It is defined as a roundabout or indirect way of speaking. Thus, it "compensates for gaps in a language learner's knowledge" (Salomon \& Marsal, 1997, p. 473).

- Approximation: It is also another useful strategy that helps learners use a term that expresses the meaning of the target lexical item as closely as possible (superordinate terms, e.g., ship for sailing boat or animal for horses).

- All-purpose words: (e.g., thing, stuff), as suggested by Dornyei and Thurrell (1992), can be resorted to when learners are not sure about a superordinate term.

- Lexicalized fillers: They are words or gambits used to fill pauses and to gain time to think in order to keep the communication channel open and maintain discourse when speakers face communicative problems.

To design the lessons for this study, a number of activities suggested by different researchers for the teaching of communication strategies (e.g., Dornyei, 1995; Dornyei \& Thurrell, 1991; Willems, 1987) or of English as a foreign/second language (e.g., Doff, 1990; Harmer, 1991) was used. In addition, some activities to teach abstract words, an aspect that has not been touched in other studies, were created.

As noted above, 40 homogenous learners were randomly assigned to two different groups of twenty participants. There were one experimental and one control group.

During the treatment phase of the study, participants in both groups separately attended eight sessions of instruction in which they were involved in communication in English.

As for the participants in the control group, no special material was designed for handling the class and the teacher, who was the researcher himself, went through the normal routine procedure of teaching the materials available for the course in the institute. The materials consisted of miscellaneous tasks and activities via listening, speaking, reading, and writing, each of which was immediately followed activities to foster discussions to the extent possible in order to maintain maximum chances for communication.

In the experimental group, however, the participants were made aware of the availability of different strategies to get rid of problems and difficulties in case they arouse in the course of communication. The four strategies at focus approximation, all-purpose words, circumlocution and fillers- described above, were brought up occasionally during the lessons and then summarized and reviewed at the end of the class. The main part of the treatment was when the teacher 
explicitly explained and emphasized on the importance of communication strategies. This was done by utilizing eight different lessons, which were all well-designed in terms of objectives, materials, and tasks.

Each strategy was taught according to the following procedures, based on the methodological theory of English language teaching suggested by Doff (1990) and Harmer (1991):

- Presentation stage: Students were introduced with clear instruction about the strategy they were going to study, including its meaning, its form, and its use. Information handouts that contained phrases for the employment of the strategies studied were given to the students.

- Practice stage: Students were asked to do some tasks to practice using the strategy either in isolation or in given contexts. In this stage, the teacher could provide some intervention while the students were doing the task to ensure that they were on the right track. The students could use the information handouts for reference.

- Production stage: In this stage, the students were required to manage the tasks by themselves without any help from the teacher or the handouts. The teacher gave feedback only after the students had completed the task. In this stage, students were encouraged to do their best to use the language as individuals and arrive at a degree of language autonomy.

- The last lesson was devoted to the consolidation of the teaching session in which students were encouraged to use all the strategies they had learned, where it was necessary, to perform a task. Students had complete freedom to choose the words, structures, and content to express their ideas.

Having completed the treatment phase of the study, the researcher set out to gauge the learners' mastery of the communication strategies in question. For this purpose, the participants in the experimental group were randomly assigned to two groups, each of which had 10 participants. One group was given the instruction task of how to drive a car. The other group was given the narrative task, which demanded the participants to talk about their last trip in detail. All interviews were conducted by the researcher, who was also the teacher.

\section{Posttest Interview}

Participants in both experimental and control groups took a posttest interview which consisted of a different set of questions (Appendix B). The interviews were transcribed and then rated based on the measures chosen for complexity, accuracy, and fluency.

\section{E. Measures}

In order to ensure comparability of the results of the present study with previous research, measures that were already used in similar studies were utilized. The following measures were used in this study to examine each of the three factors.

Fluency: Total number of pauses - It was calculated by counting the number of pauses of one second or more. Following Mehnert (1998), no distinction was made between unfilled pauses and pauses that included fillers such as $\mathrm{hm}$, urn, and uh. This measure was used in Foster and Skehan (1996), Foster and Skehan (1999), Mehnert (1998).

Complexity: Proportion of dependent clauses per AS unit (Wigglesworth \& Elder 2010). AS-unit is defined as "a single speaker's utterance consisting of an independent clause, or sub-clause unit, together with any subordinate clause(s) associated with either" (Foster et al., 2000, p. 365; emphasis in the original). AS-unit is a syntactic measure that additionally uses pause and intonation phenomena to cut oral data into independent AS-units. Earlier studies (Crookes, 1989; Foster \& Skehan, 1999) used a similar c-unit, defined as each independent utterance providing referential or pragmatic meaning. Thus, a c-unit may be made up of one simple independent finite clause or else an independent finite clause plus one or more dependent finite/non-finite clauses (Foster \& Skehan, 1999, pp. 228-229). Tunit, c-unit, and AS-unit differ in that they allow for the inclusion of progressively more data in the analysis of the second language speech, which is known for being fragmentary.

Accuracy: Percentage of error-free clauses - This is a generalized measure of accuracy, and was found to be sensitive to detecting differences in students' speech (Foster \& Skehan, 1996). This measure was used in Foster and Skehan (1996), Foster and Skehan (1999), Yuan and Ellis (2003), Wigglesworth and Elder (2010).

To determine inter-rater reliability, ten oral recordings were randomly selected from the data. A trained rater and the researcher coded the data using the measures described above. Inter-rater reliability was determined by looking at the percentage of agreement between the raters. Pearson Product Moment correlation coefficients for the scores of the two coders ranged from .92 to 0.81 , with only one below .90 .

\section{DATA ANALYSis}

Each tape-recorded interview was transcribed. All the transcripts were coded using three measures covering fluency, accuracy, and complexity as discussed above. An independent-samples t-test was conducted to compare CAF of learners' oral production in control and experimental groups (i.e., with and without strategy instruction). Inter-rater reliability coefficients were obtained on all categories identified for analysis by two raters working independently. The analysis of the recorded audios was carried out by the researcher and a research assistant. Inter-rater reliability was above $88 \%$ on all measures. 


\section{RESUlTS}

The research question addressed the effect of strategy instruction on complexity, accuracy, and fluency of Iranian intermediate EFL learners' oral production. In response to this question, a series of t-tests were carried out on each dependent variable in order to determine for which measures differences reached significance. The minimum alpha for confirmation of the research hypothesis was .05. At first the descriptive data for the three complexity, accuracy, and fluency measures are displayed in Table I. Similarly, summary of the results from the t-test is displayed in Table II.

TABLE I.

DESCRIPTIVE STATISTICS FOR STRATEGY INSTRUCTION AND CAF

\begin{tabular}{|cc|c|c|c|c|}
\hline & Group & $\mathrm{N}$ & Mean & Std. Deviation & Std. Error Mean \\
\hline \multirow{2}{*}{ Complexity } & Control & 20 & 1.410 & .3417 & .0764 \\
& Experimental & 20 & 1.775 & .2573 & .0575 \\
\hline \multirow{2}{*}{ Accuracy } & Control & 20 & 41.000 & 4.8123 & 1.0761 \\
& Experimental & 20 & 45.150 & 4.0817 & .9127 \\
\hline \multirow{2}{*}{ Fluency } & Control & 20 & 21.700 & 4.9108 & 1.0981 \\
& Experimental & 20 & 27.150 & 3.8289 & .8562 \\
\hline
\end{tabular}

TABLE II.

INDEPENDENT SAMPLE T-TESTS BETWEEN STRATEGY INSTRUCTION AND CAF

\begin{tabular}{|c|c|c|c|c|c|c|c|c|c|c|}
\hline & & \multicolumn{2}{|c|}{$\begin{array}{l}\text { Levene's Test for } \\
\text { Equality of Variances }\end{array}$} & \multicolumn{7}{|c|}{ t-test for Equality of Means } \\
\hline & & \multirow[t]{2}{*}{$\mathrm{F}$} & \multirow[t]{2}{*}{ Sig. } & \multirow[t]{2}{*}{$\mathrm{t}$} & \multirow[t]{2}{*}{ df } & \multirow[t]{2}{*}{$\begin{array}{l}\text { Sig. }(2- \\
\text { tailed) }\end{array}$} & \multirow[t]{2}{*}{$\begin{array}{l}\text { Mean } \\
\text { Difference }\end{array}$} & \multirow[t]{2}{*}{$\begin{array}{l}\text { Std. Error } \\
\text { Difference }\end{array}$} & \multicolumn{2}{|c|}{$\begin{array}{l}\text { 95\% Confidence } \\
\text { Interval of the } \\
\text { Difference }\end{array}$} \\
\hline & & & & & & & & & Lower & Upper \\
\hline \multirow{2}{*}{ Complexity } & $\begin{array}{l}\text { Equal variances } \\
\text { assumed }\end{array}$ & 1.614 & .212 & & 38 & & & & & \\
\hline & $\begin{array}{l}\text { Equal variances not } \\
\text { assumed }\end{array}$ & & & -3.817 & 35.304 & .001 & -.3650 & .0956 & -.5591 & -.1709 \\
\hline \multirow{2}{*}{ Accuracy } & $\begin{array}{l}\text { Equal variances } \\
\text { assumed }\end{array}$ & .087 & .770 & & & & & & & \\
\hline & $\begin{array}{l}\text { Equal variances not } \\
\text { assumed }\end{array}$ & & & & 37.014 & .006 & & 1.4110 & & -1.2911 \\
\hline \multirow{2}{*}{ Fluency } & $\begin{array}{l}\text { Equal variances } \\
\text { assumed }\end{array}$ & 2.785 & .103 & -3.914 & 38 & .000 & -5.4500 & 1.3924 & -8.2688 & -2.6312 \\
\hline & $\begin{array}{l}\text { Equal variances not } \\
\text { assumed }\end{array}$ & & & -3.914 & 35.867 & .000 & -5.4500 & 1.3924 & -8.2743 & -2.6257 \\
\hline
\end{tabular}

The mean scores and standard deviations of the complexity, accuracy, and fluency measures (i.e., proportion of dependent clauses per AS unit, percentage of error-free clauses, and total number of pauses, respectively) with respect to control and experimental groups are presented in Table I. The mean scores for all the three measures are higher in the experimental group, indicating that participants in the experimental group tended to produce language which was more complex, accurate, and fluent.

The results of the t-tests, illustrated in Table II, show that there is a statistically significant difference $(p<.05)$ between the control and experimental group, regarding complexity, accuracy, and fluency measures. The mean of all measures are greater in the strategy instruction group, indicating that strategy instruction resulted in more complex, accurate, and fluent oral production. Thus, the first null hypothesis predicting that explicit strategy instruction will have no effect on intermediate Iranian EFL learners' oral production in terms of accuracy, complexity, and fluency is rejected.

To conclude, analyzing the results obtained from the experimental and the control groups with regard to the effect of strategy instruction on the complexity, accuracy, and fluency of oral performance, deductions can be made that strategy instruction benefited all the three characteristics of responses.

\section{CONCLUSION}

This study was designed to investigate whether it was effective to teach learners how to use communicative strategies (i.e., circumlocution, approximation, all-purpose words, lexicalized fillers).

The research question addressed the effect of explicit strategy instruction on complexity, accuracy, and fluency of Iranian intermediate learners' oral production. Findings suggest that strategy instruction benefited oral performance and the experimental group reached a higher level of complexity, accuracy, and fluency. This finding is in line with that of Dornyei (1995), Faerch and Kasper (1983), Tarone (1984), and Willems (1987), while runs contradictory to that of Bialystok (1990), Bongaerts and Poulisse (1989). According to Dornyei (1995), making learners more conscious of 
strategies that already exist in their repertoire could be very helpful for them when they lack specific vocabulary items. Faerch and Kasper (1986) also stress the need to increase learners' "meta-communicative awareness" concerning strategy use.

Regarding strategic performance, the results show that fostering communication strategies may have a positive effect on language learners' strategic competence, i.e. strategically aware learners perform with a higher degree of complexity, accuracy, and fluency. Thus, it lends support to researchers who advocate direct teaching of communication strategies to language learners (Dornyei, 1995; Salomon \& Marsal, 1997; Scullen \& Jourdain, 1999; Tarone \& Yule, 1989).

In this study, the teaching of approximation, all-purpose words, circumlocution, and lexicalized fillers was known to be effective in helping the learners get their meaning across. Similar results can be found in the studies conducted by Brodersen and Gibson (1982), Mosiori (1991), Dornyei (1995), Salomon and Marsal (1997), Russell and Loschky (1998), Scullen and Jourdain (1999), Dula (2001), Brett (2001), and Rossiter (2003).

It is obvious that communication strategy use does exist in the learner's native language and thus can be transferred to his/her communication in the target language (Bialystok, 1990; Bongaerts \& Poulisse, 1987; Poulisse, 1989). Yet, this is not always the case. Not every learner is equally adept at using communication strategies or commands the same range of communication strategies (Berry-Bravo, 1993; Russell \& Loschky, 1998; Willems, 1987). This study lends support to the results that the latter group of authors found in their researches.

The present study also provides support to claims made by Canale (1983), Savignon (1983), Rubin (1987), Willems (1987), Rost (1994), and Dornyei (1995) regarding the teaching of lexicalized pause fillers which help speakers gain time to think and keep the communication channel open. Their findings were consistent with our interests in providing instruction in the use of strategies for speaking in a foreign language. The data show that the students had not used or even had not known about lexicalized fillers until they learned how to use them in the strategy class. Instead, they tended to produce pauses or use non-lexicalized fillers such as "er" when they faced a vocabulary gap. Yet, after the lesson about fillers, they employed this strategy in their talk and thus their fluency has been, to some extent, enhanced.

Explicit strategy instruction proved to benefit learners' oral performance with regard to complexity, accuracy, and fluency. The use of strategies unquestionably boosted the learners' ability to communicate more easily and to circumvent the problems they encountered. In summary, the result of this study regarding the effect of explicit strategy instruction on complexity, accuracy, and fluency of oral production is in harmony with the findings of the previously conducted research in the area, which generally concluded that strategy instruction facilitates oral production.

Despite the fact that there is no doubt about the need to conduct more research as to the efficacy of explicit strategy instruction, and especially to follow the empirical studies that highlight the significance of strategy instruction to improve oral performance, this study has to put forth suggestions for instructional changes in the classroom.

This study was primarily undertaken to cast light on the issue of strategy instruction to determine whether it should have a role in foreign language classrooms. If foreign language teachers methodically introduce and reinforce strategies, the learners will significantly improve their oral performance.

\section{APPENDIX A: PRETEST INTERVIEW QUESTIONS}

1. What is your name?

2. How old are you?

3. Where are you from?

4. What is your field of study?

5. What are your interests?

6. What number child are you in your family?

7. How do you spend your free time?

8. What do you do?

9. What do you like to be in future?

10. Are you interested in sports?

11 . What sports do you play or watch?

12. What do you hope you'll have achieved by the time you are forty?

13. What are your plans for future?

14. Are you happy with your life?

15. Have you ever been abroad?

16. What kind of person are you?

17. What's your hometown like?

APPENDIX B: PostTEST INTERVIEW QUESTIONS

1. What is your name?

2. How old are you?

3 . Where are you from?

4. What is your field of study? 
5. What is the most exciting sport you have ever played? Explain some of the rules of this sport.

6. Are you in favor of science fiction stories? Why?

7. Who is your favorite actor? What does he look like?

8. What do you regret about past?

9. Do you agree with this sentence: "History repeats itself"?

10. What are some of the difficulties of a minor's job?

11. Where do you wish you could live?

12. How do you evaluate your performance in last five years?

13. When did you last go to the theater? What did you watch?

\section{ACKNOWLEDGMENT}

The authors are grateful to the Office of Graduate Studies at the University of Isfahan for their support.

\section{REFERENCES}

[1] Bachman, L. F. (1990). Fundamental considerations in language testing. New York: Oxford University Press.

[2] Berry-Bravo, J. (1993). Teaching the art of circumlocution. Hispania, 76, 371-377.

[3] Bialystok, E. (1990). Communication strategies. Boston: Blackwell.

[4] Bongaerts, T., \& Poulisse, N. (1989). Communication strategies in LI and L2: Same or different? Applied Linguistics, 10, 253258.

[5] Bongaerts, T., Kellerman, E., \& Bentlage, A. (1987). Perspectives and proficiency in L2 referential communication. Studies in Second Language Acquisition, 9(2), 171-199.

[6] Brett, A. G. (2001). Teaching communication strategies to beginners. Language Learning Journal, 24, 53-61.

[7] Brodersen, A., \& Gibson, J. (1982). Discussions of communication strategies among language learners. English Teaching Forum, 56, 24-32.

[8] Bygate, M., Skehan, P., \& Swain, M. (2001). Researching pedagogic tasks: Second language learning, teaching and testing. London: Longman.

[9] Canale, M. (1983). From communicative competence to communicative language pedagogy. In J. Richard \& R. Schmidt (Eds.), Language and communication (pp. 2-27). London: Longman.

[10] Canale, M., \& Swain, M. (1980). Theoretical bases of communicative approaches to second language teaching and testing. Applied Linguistics, 7(1), 1-47.

[11] Chomsky, N. (1965). Aspects of the theory of syntax. Cambridge, MA: MIT Press.

[12] Corder, S. P. (1983). Strategies of communication. In C. Faerch \& G. Kasper (Eds.), Strategies in interlanguage communication (pp. 15-19). London: Longman.

[13] Crookes, G. (1989). Planning and interlanguage variation. Studies in Second Language Acquisition, 11, $367-383$.

[14] Doff, A. (1990). Teach English. Cambridge, England: Cambridge University Press.

[15] Dornyei, Z. (1995). On the teachability of communication strategies, TESOL Quarterly, 29(7), 55-85.

[16] Dornyei, Z., \& Thurrell, S. (1991). Strategic competence and how to teach it. ELT Journal, 45, 16-23.

[17] Dornyei, Z., \& Thurrell, S. (1992). Conversation \& dialogues in action. Hemel Hempstead, England: Prentice-Hall.

[18] Dula, E. L. (2001). The effects of communication strategy training on foreign language learners at the university level. Unpublished doctoral dissertation, Temple University.

[19] Ellis, R. (1987). Interlanguage variability in narrative discourse: Style shifting in the use of the past tense. Studies in Second Language Acquisition, 9, 12-20.

[20] Ellis, R. (2003). Task-based language learning and teaching. New York: Oxford University Press.

[21] Faerch, C, \& Kasper, G. (1980). Process and strategies in foreign language learning communication. Interlanguage Studies Bulletin, 5, 47-118.

[22] Faerch, C, \& Kasper, G. (1983). Strategies in interlanguage communication. Harlow, England: Longman.

[23] Faerch, C, \& Kasper, G. (1986). Strategic competence in foreign language teaching. In G. Kasper (Ed.), Learning, teaching and communication in the foreign language classroom (pp. 179-194). Aarhus, Denmark: Aarhus University Press.

[24] Foster, P., \& Skehan, P. (1996). The influence of planning and task type on second language performances. Studies in Second Language Acquisition, 18, 299-323.

[25] Foster, P., \& Skehan, P. (1999). The influence of source of planning and focus of planning on task-based performance. Language Teaching Research, 3(3), 215-247.

[26] Foster, P., Tonkyn, A., \& Wigglesworth, G. (2000). Measuring spoken language. Applied Linguistics, 21(3), 354-375.

[27] Harmer, J. (1991). The practice of English language teaching. London: Longman.

[28] Hymes, D. H. (1972). On communicative competence. In J. Pride \& J. A. Holmes (Eds.), Sociolinguistics: Selected readings (pp. 95-125). Harmondsworth, England: Penguin Books.

[29] Mehnert, U. (1998). The effects of different length of time for planning on second language performance. Studies in Second Language Acquisition, 20(1), 83-108.

[30] Mosiori, K. K. (1991). The effects of consciousness-raising about communication strategies on the second language strategic performance of adult learners of French as a foreign language. Unpublished doctoral dissertation, University of Toronto.

[31] Oxford, R. L. (1990). Language learning strategies: What every teacher should know. Boston: Heinle \& Heinle.

[32] Poulisse, N. (1989). The use of compensatory strategies by Dutch learners of English. Enschede, The Netherlands: Sneldruk.

[33] Richards, J., \& Schmidt, R. (2002). Dictionary of language teaching and applied linguistics. London: Pearson Education. 
[34] Rossiter, M. J. (2003). "It's like chicken but bigger": Effects of communication strategy in the ESL classroom. Canadian Modern Language Review, 60(2), 105-121.

[35] Rost, M. (1994). Communication strategies: Are they teachable? Paper presented at TESOL '94, Baltimore, MD.

[36] Rubin, J. (1987). Learner strategies: Theoretical assumptions, research history and typology. In A. Wenden \& J. Rubin (Eds.), Learner strategies in language learning. Hertsfordshire, England: Prentice-Hall International.

[37] Russell, G., \& Loschky, L. (1998). The need to teach communication strategies in the foreign language classroom. JALT Journal, 20(1), 100-114.

[38] Salomon, A. M., \& Marsal, F. (1997). How to avoid breakdown? Circumlocution! Foreign Language Annals, 30(4), $473-358$.

[39] Savignon, S. J. (1983). Communicative competence: Theory and classroom practice. New York: McGraw-Hill.

[40] Scullen, M. E., \& Jourdain, S. (1999). The effect of explicit training on successful circumlocution: A classroom study. In J. F. Lee \& A. Valdman (Eds.), Form and meaning: Multiple perspectives (pp. 231-251). Boston: Heinle \& Heinle.

[41] Tarone, E. (1977). Conscious communication strategies in interlanguage: A progress report. In H. Brown, C. Yorio, \& R. C. Crymes (Eds.), On TESOL' 77 (pp. 194-203). Washington, DC: TESOL.

[42] Tarone, E. (1980). Communication strategies, foreign talk and repair in interlanguage. Language Learning, 30, 417-431.

[43] Tarone, E. (1983). Some thoughts on the notion of communication strategy. In C. Faerch \& G. Kasper (Eds.), Strategies in interlanguage communication (pp. 61-78). Harlow, England: Longman.

[44] Tarone, E., \& Yule, G. (1989). Focus on language learner. Oxford, England: Oxford University Press.

[45] Tarone, E., Cohen, A., \& Dumas, G. (1976). A close look at some interlanguage terminology: A framework for communication strategies. Working Papers on Bilingualism, 9, 76-90.

[46] Wigglesworth, G., \& Elder, C. (2010). An investigation of the effectiveness and validity of planning time in speaking test tasks. Language Assessment Quarterly, 7(1), 1-24.

[47] Willems, G. (1987). Communication strategies and their significance in foreign language teaching. System 15(3), $351-364$.

[48] Yuan, F., \& Ellis, R. (2003). The effect of pre-task planning and on-line planning on fluency, complexity, accuracy in L2 monologic oral production. Applied Linguistics, 23(1), 1-27.

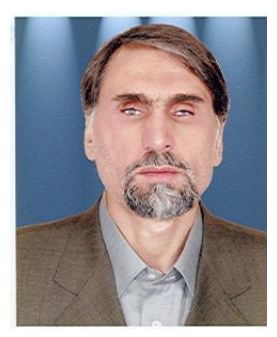

Mansoor Tavakoli has a PhD in applied linguistics and is an assistant professor at the University of Isfahan. He has been involved with teaching TEFL courses for over 15 years at the University of Isfahan. His research interests are in the areas of second language acquisition, second language teaching and assessment. He has published several articles in these respects.

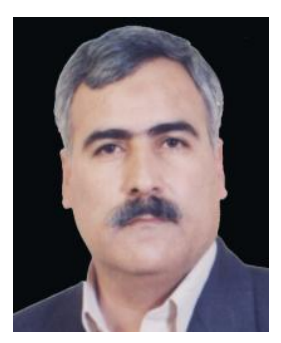

Hossein Vahid Dastjerdi teaches in the English Language Department at the University of Isfahan, Iran. He is associate professor of applied linguistics and has taught courses of variegated character, including translation courses, for years. He has been a fellow of the English Centers at the universities of Isfahan and Shiraz where he has investigated into issues related to materials preparation for GE and ESP courses. He is the author of a number of books in this respect. He has also published a good number of articles on discourse, testing and translation in local and international journals.

Dr. Vahid's current research interests include testing, materials development, translation, the metaphoricity of language, discourse analysis, pragmatics and critical discourse analysis. He is presently involved in a number of projects concerning translation studies as well as figurative language use.

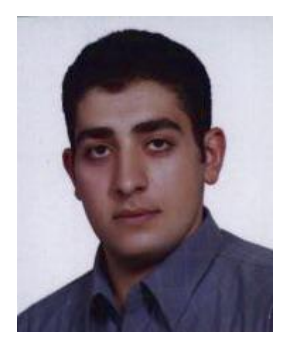

Masood Esteki received his B.A. in English Language and Literature at University of Isfahan in 2007. He also did an M.A. in TEFL at the same university in March, 2011. He has been teaching English since 2004. His areas of interest are: Language Assessment and Language Teaching Methodology. 